\title{
The Effect of a Hypothetical Artificial Recharge Program on Water Table Altitudes of Shallow Dibdibba Sandy Aquifer in Safwan- Zubair Area, South of Iraq
}

\author{
Alaa M. Atiaa \\ Department of Geology \\ College of Science \\ Basrah University
}

\author{
Monera N. Sadoon \\ Department of Civil Engineering \\ South Oil Company \\ Basrah
}

(Received 30/11/2005, Accepted 21/1/2007)

\begin{abstract}
A two-dimensional numerical based model is constructed to simulate the flow system of Dibdibba Sandy aquifer in Safwan-Zubair area, south of Iraq. A trial and error method is used to calibrate the model in two sequential stages: steady and transient states. Sensitivity analysis showed that the model is sensitive and less sensitive to change hydraulic conductivity and specific yield, respectively. The calibrated model is utilized to predict behavior of the aquifer over a planning horizon of 10 years (2001-2010) under two management alternatives. Based on the management alternative I which is depending on the fact that the operating wells is growing with a rate of 200 wells per year, a continuous decline of groundwater levels will occur if the model is run without recharging the aquifer. Average decline of head is of about $(2 \mathrm{~m})$. In the application of artificial recharge, the case is reversed. In most of the observation wells, the values of simulated head are rise and then decline gradually to a level that observed in the beginning of simulation period. The average rise in water table altitudes is $(0.56 \mathrm{~m})$. The results of the alternative II, which is depending on increase of discharge of each operating wells within the area of concern from $5 \mathrm{l} / \mathrm{s}$ to $7 \mathrm{\ell} / \mathrm{s}$, are similar the first alternative where the averages decline and rise of water table altitudes are $(0.85$ and $0.88 \mathrm{~m})$ respectively.
\end{abstract}
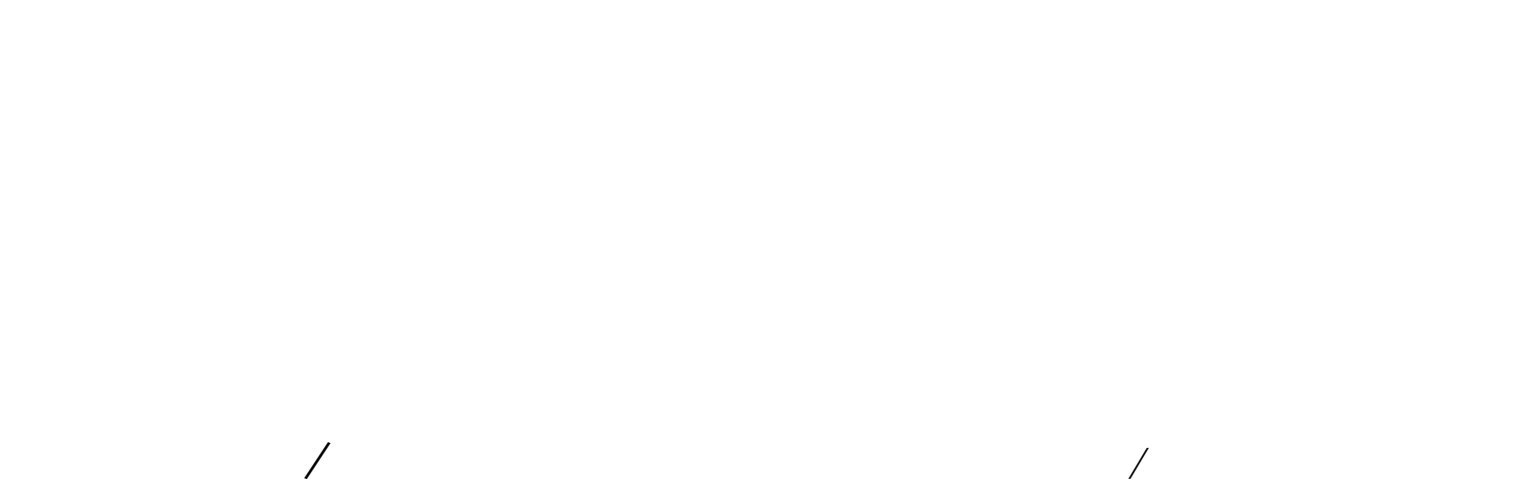

الملغص

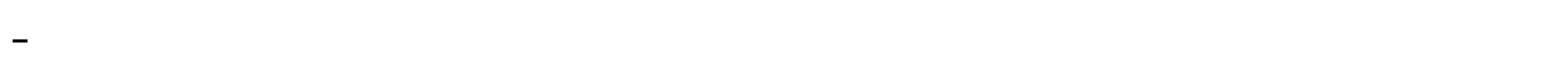

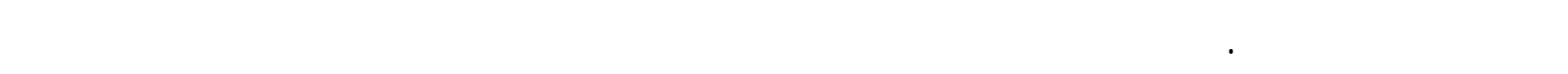

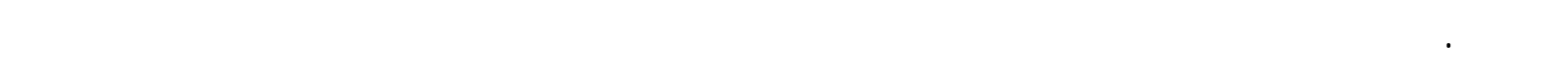

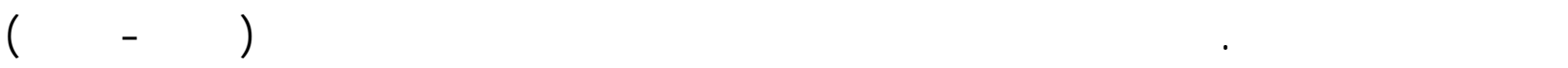


تحت خطتي ظطوير مفترضتين. تضضمت الخطة الاوله زياة عدد الآبار العلملة في المظقة بمعل زياة

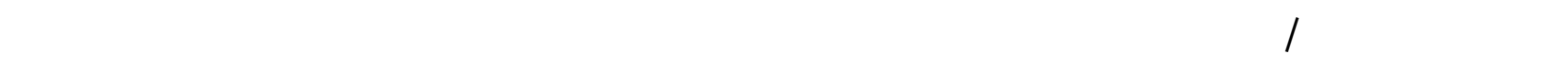

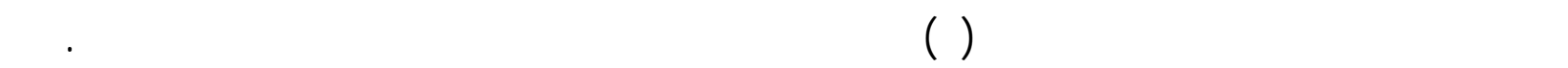

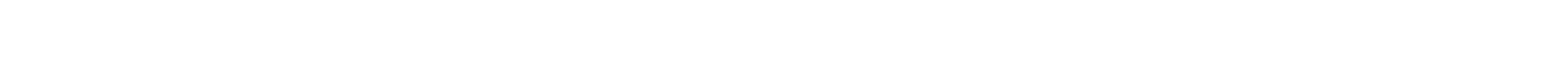

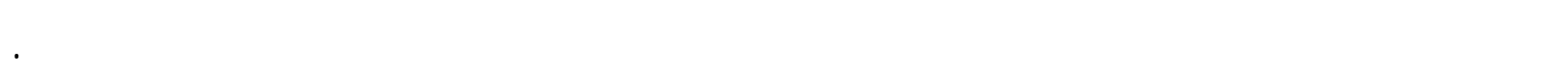

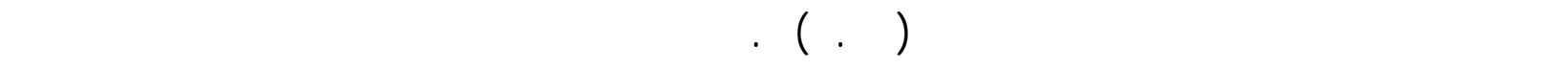

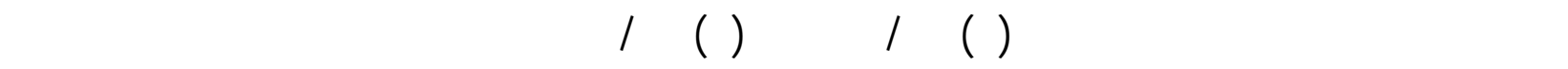

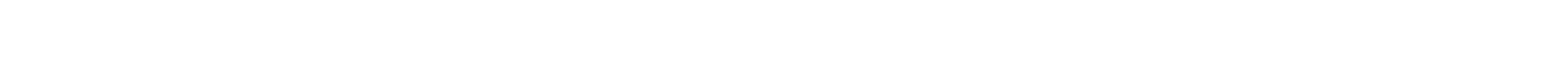

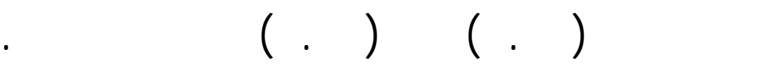

\section{INTRODUCTION}

Since the 1950's, groundwater has been abstracted from both shallow and deep parts of the unconsolidated deposits in the Safwan-Zubair area, south of Iraq, to irrigate primarily tomato, reaching a peak annual extraction of more than $\left(192 \times 10^{6} \mathrm{~m}^{3}\right)$ with year 2003. Prolonged groundwater extraction in excess of the natural rate of replenishment has critically lowered groundwater levels in the exploited aquifer. Also, this has resulted in degrade quality of groundwater supplied in some areas as a result of induced inflows of poor quality waters form deeper in the aquifer system.

Over the last three decades several numbers of studies and investigations have been implemented (Haddad and Hawa, 1979; Al-Rawi et al., 1983; Al-Jawad et al., 1989; Al-Kubaisi, 1999; Al-Suhail, 1999; Al-Abadi, 2002; Atiaa, 2005; and Al-Suhail et al., 2005) resulted in a better understanding of the physical and chemical characteristics of the shallow upper parts of hydrogeological system in the area being question. Most of these studies showed that the usable unconfined aquifer follows the direction of mining of resource; i.e., the aquifer is in overdraft conditions.

The aim of this study is to develop a simulation model to assess the effects of future groundwater withdrawals and to provide a tool suitable to evaluate the potential for hypothetical large-scale artificial recharge program. The primary objective of this program is to halt, and hopefully reverse, the long term decline of groundwater levels.

\section{PHYSICAL SETTING}

Safwan-Zubair area is apart of the southeastern limits of the Iraq Western Desert (Fig. 1). It covers about $\left(1235 \mathrm{~km}^{2}\right)$ from the total area of Dibdibba plain and consists of the widespread sandy surface (Fig. 2), dipping gently towards the southwest and westwards. It has not any complex geomorphologic features except ambiguous Jabal Sanam in origin and some depressions. The lithological composition ensures that the Dibdibba Formation was deposited under fluviatic to deltic environments (Buday, 1981). Sand, gravel, silt interbeded with clay beds and rare gypsum represent the main deposits of the formation, which originates from Tertiary to Quaternary Periods. Lack of the fossils is imputed to an oxidizing environment together with reworking of the deposits. The area is affected by system of deep subsurface faults extended from northeast to southwest (Buday and Jassim, 1989). 


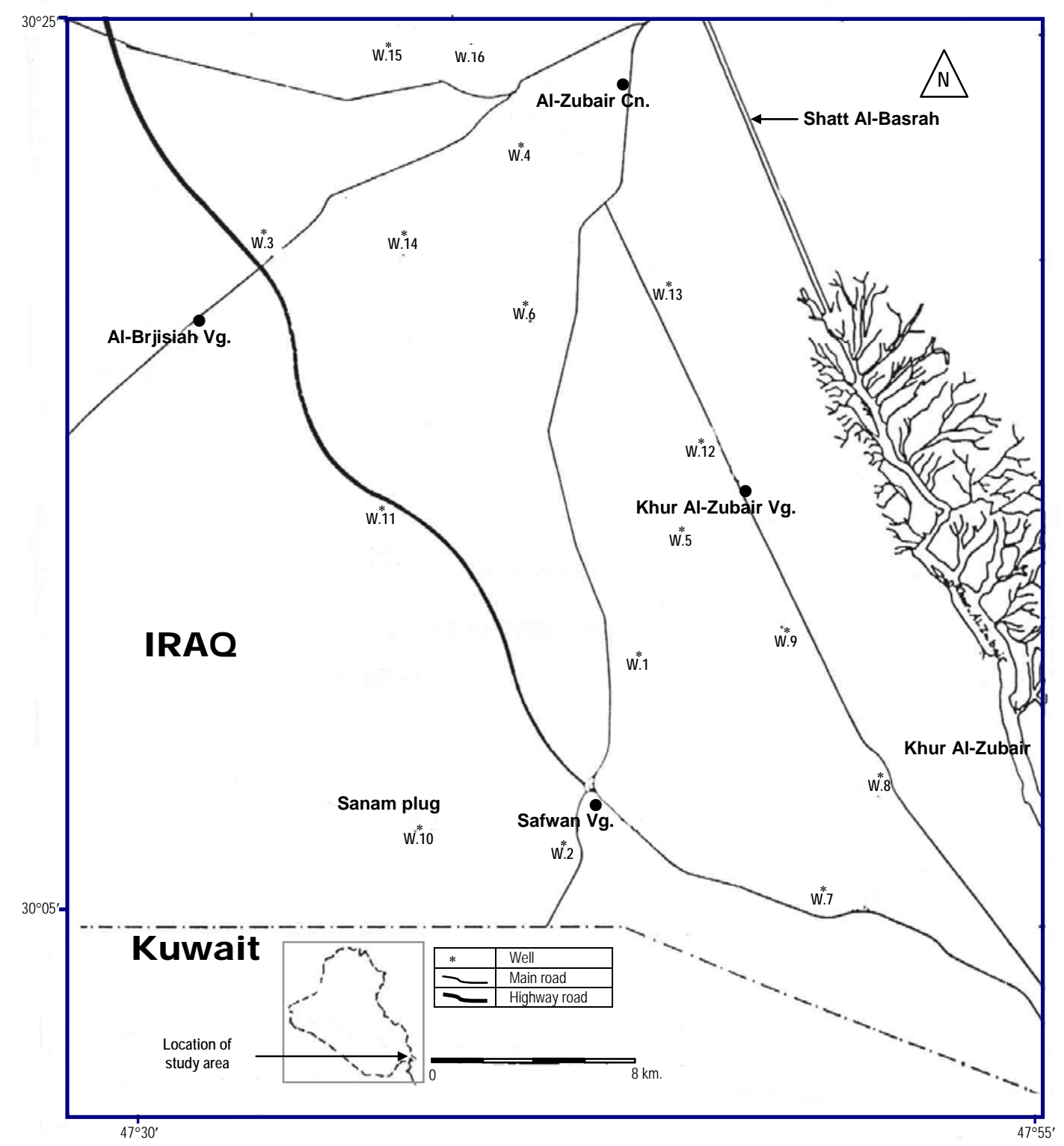

Fig. 1: Location map of the study area.

The area being question is characterized by the arid to semi-arid climate, where the total average of rainfall is about $(140 \mathrm{~mm})$. The annual average of temperature is $\left(33.30{ }^{\circ} \mathrm{C}\right)$, while total annual average of evaporation is $(3534 \mathrm{~mm})$. Large diameter hand dug pumping wells were drilled randomly with non-uniform shapes since the fourth decades end of the past century (Haddad and Hawa, 1979). Currently, these wells reach much more than 5000 wells. The pumping period is nearly most of the day hours, which extended to $(12 \mathrm{~h} / \mathrm{d})$ in November to May and $(24 \mathrm{~h} / \mathrm{d})$ in August, September and October. The maximum total annual period of irrigation is about (198d) (Al-Abadi, 2001). In the study area, there are two manners for irrigation, the furrow method that became scarce due to using of trickle irrigation method. The first choice is applied by $(15 \%)$ of farms while the second is applied by $(85 \%)$, where a percentage of re-infiltrated groundwater is (84\%) (Haddad and Hawa, 1979) and (33\%) (Nomas and Al-Asadi, 2001) in furrow and trickle, respectively. 


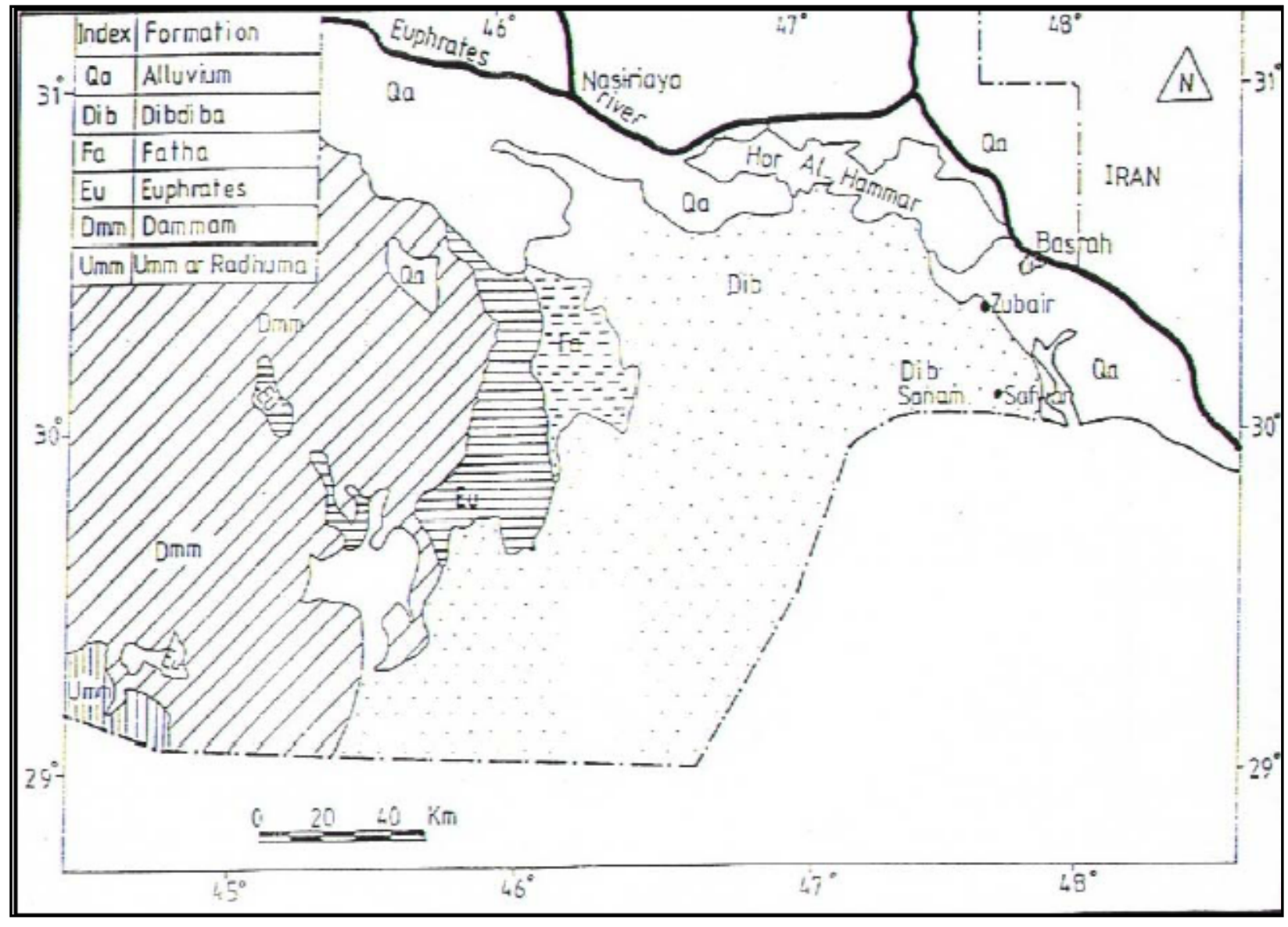

Fig. 2 : Regional distribution of Dibdibba Sandy surface in Iraq.

\section{HYDROGELOGICAL AND GEOLOGICAL SETTINGS}

The upper part of Dibdibba Formation, in which the most productive units are sand and gravels, is the main aquifer in the study area. Owing to the hydraulic properties variations, Al-Kubasi (1999) divides the upper part of Dibdibba Formation into two hydrogologic units. One of them is unconfined (Quaternary) and the other is semi-confined (Tertiary). The unconfined aquifer represents the one that contains natural relatively brackish water. The average of its saturated thickness extends from (15 to $20 \mathrm{~m}$ ). Hard clay lenses are often disposed through the body of the aquifer. Under the exploited aquifer there is relatively regional hard clay. It acts as a confining unit separating the two aquifers (Fig. 3a). Thickness of this bed ranges between ( 1 to $3 \mathrm{~m}$ ). The hydraulic conductivity of this lenticular clayey bed is variable, but it reaches to $(0.38 \mathrm{~m} / \mathrm{d})(\mathrm{Al}-\mathrm{Kubaisi}, 1999)$. The transmissivity of the aquifer is generally greater than $\left(300 \mathrm{~m}^{2} / \mathrm{d}\right)$, while the specific yield ranges between $(0.035-0.40)$. The flow direction is generally from northeast to southwest with an average of hydraulic gradient of about 0.0018 (Al-Suhail et al., 2005).

\section{SELECTION OF NUMERICAL CODE}

A graphical user interface (GUI) computer program namely Processing Modflow for Windows (PMWIN V. 5) is selected to simulate the aquifer behavior being studied. PMWIN offers a totally integrated simulation system for modeling groundwater flow and transport process with MODFlOW-88, MODFlOW-96, PMPATH, MT3D, MT3DMS, MOC3D, PEST and UCODE (Chaing and Kinzelbach, 1998). 


\section{CONCEPTUAL MODEL}

Prior to construction of the groundwater flow model, a conceptual model of the hydrologic system is developed on the basis of previously collected data. The conceptualization of the shallow hydrologic system in Safwan-Zubair area used in this study is shown in (Fig. 3b). It is fixed for one layer. It is assumed that the base of the upper aquifer is an impermeable boundary, i.e., the activity of the deeper aquifer which requires more costly piezometric system is the main reason affecting such choice, in addition to limitations by Haddad and Hawa (1979). The two-dimension assumption is appropriate because the shallow groundwater flow system is thin and arealy extensive.

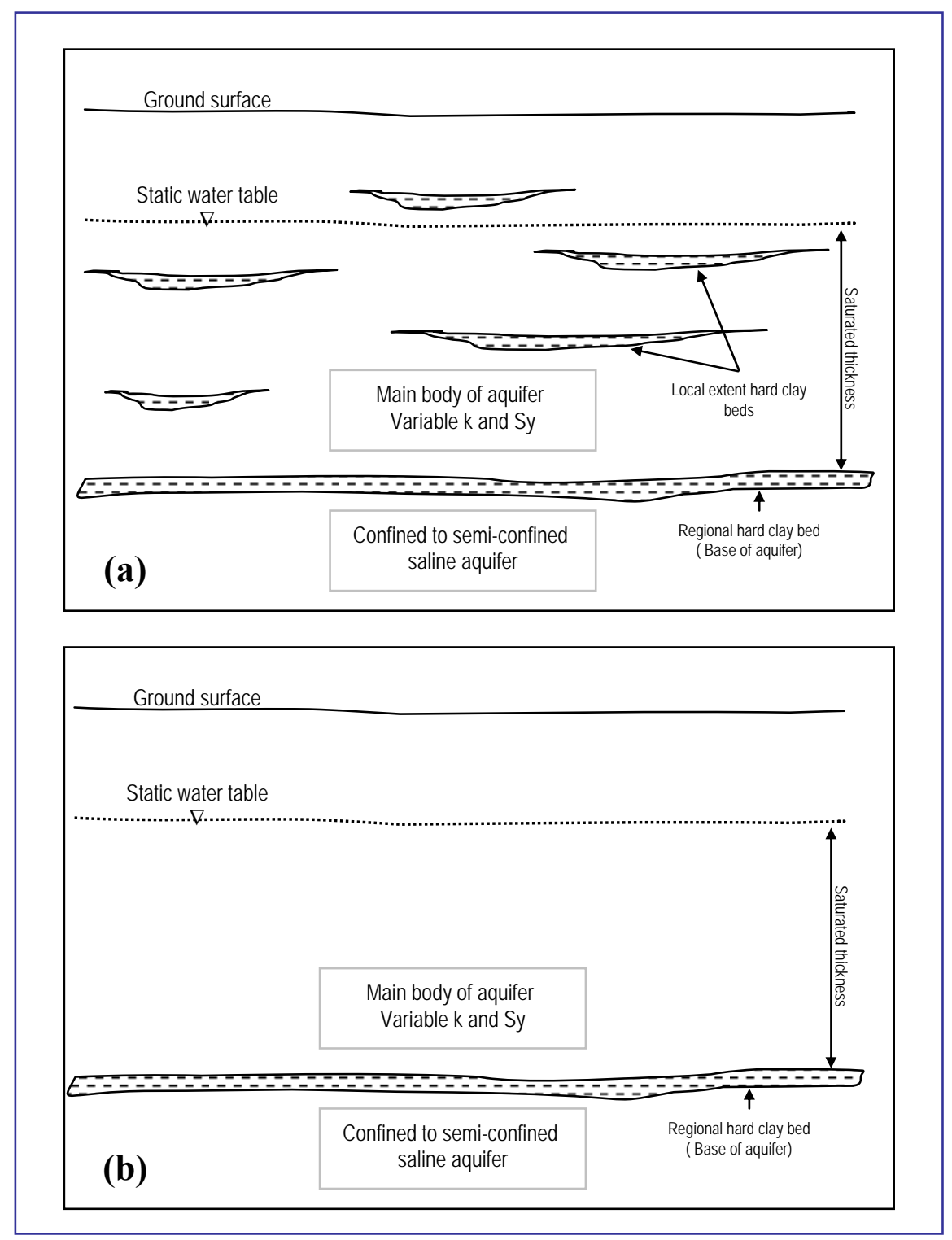

Fig. 3: (a) A prototype of Dibdibba aquifer.

(b) a conceptual model of the same aquifer. 


\section{MODEL GRID AND BOUNDARY CONDITIONS}

The area of interest is divided into a uniform grid, consisting of 93 columns and 50 rows. Thus, the total grid blocks are 7440 cells (Fig. 4). In the present model, the northern, southern edges of the area almost coincide with the flow lines (Fig. 5). Therefore, these boundaries are represented as no flow boundaries. The eastern edge of the model area is considered as constant head boundary because the canal of Shatt Al-Basrah River lies along this edge. The western boundary is modeled as headdependent boundary to allow inflow to the modeled region at a rate proportional to the head difference between the aquifer outside the simulated area and the model boundary. The top of the model is represented as unconfined aquifer. The water table elevation changes as part of the model solution. The bottom of the model is represented as a noflow condition. The vertical location of this boundary is selected to correspond with the base of the aquifer.

\section{INITIAL ASSESSMENT OF HYDRAULIC CHARACTERISTICS}

Several field studies have been conducted to assist the hydraulic characteristics of Dibdibba Formation in Safwan-Zubair area in both shallow upper and lower levels (Haddad and Hawa, 1979; Al-Jawad et al., 1989; Al-Kubaisi, 1999; and Al-Suhail et al., 2005). The spatial distribution of hydraulic properties over the model area is concluded depending on the numerical solution technique results which recently applied by Al-Suhail et al. (2005).

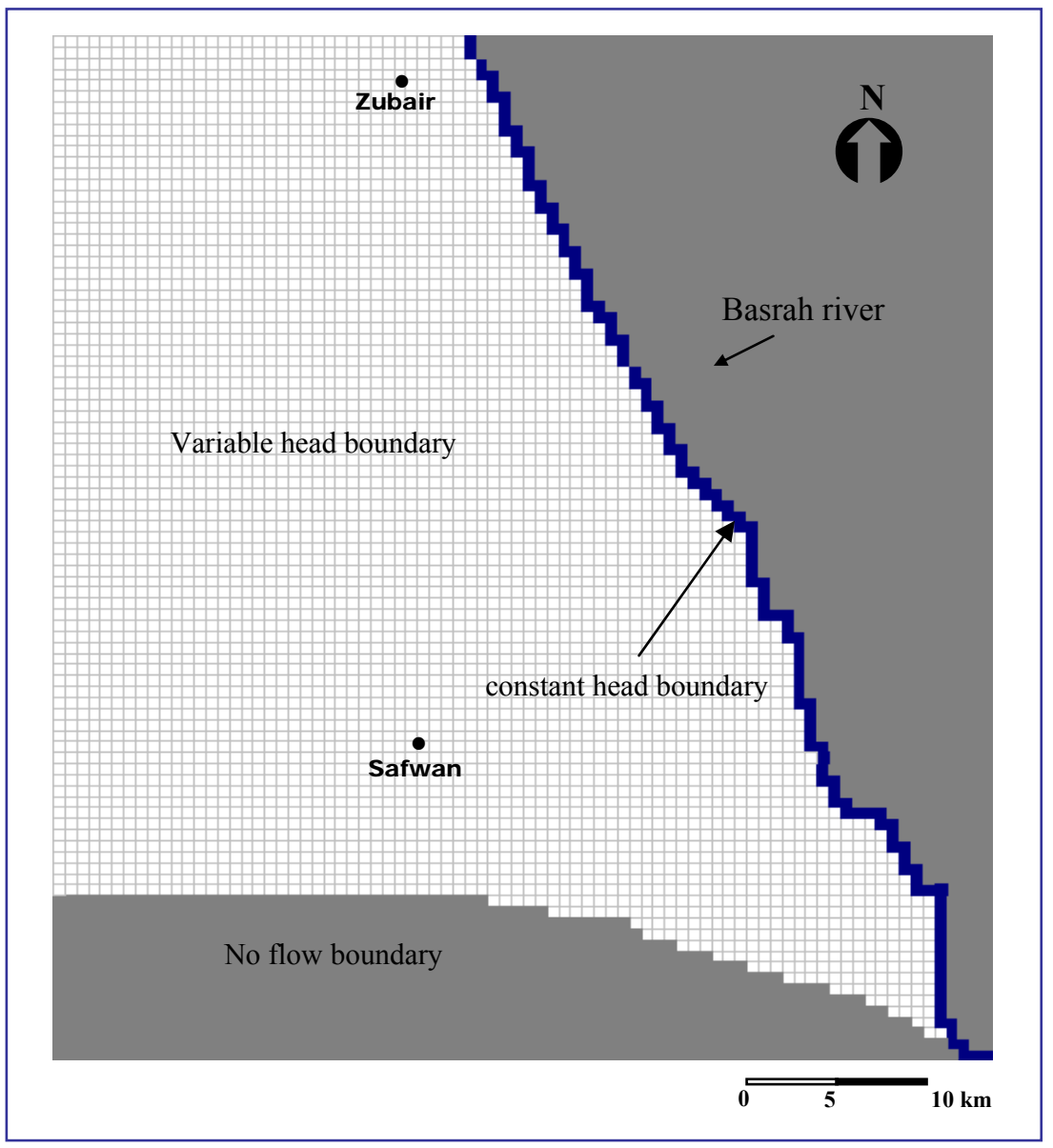

Fig. 4: Configuration of modal network and boundary conditions. 


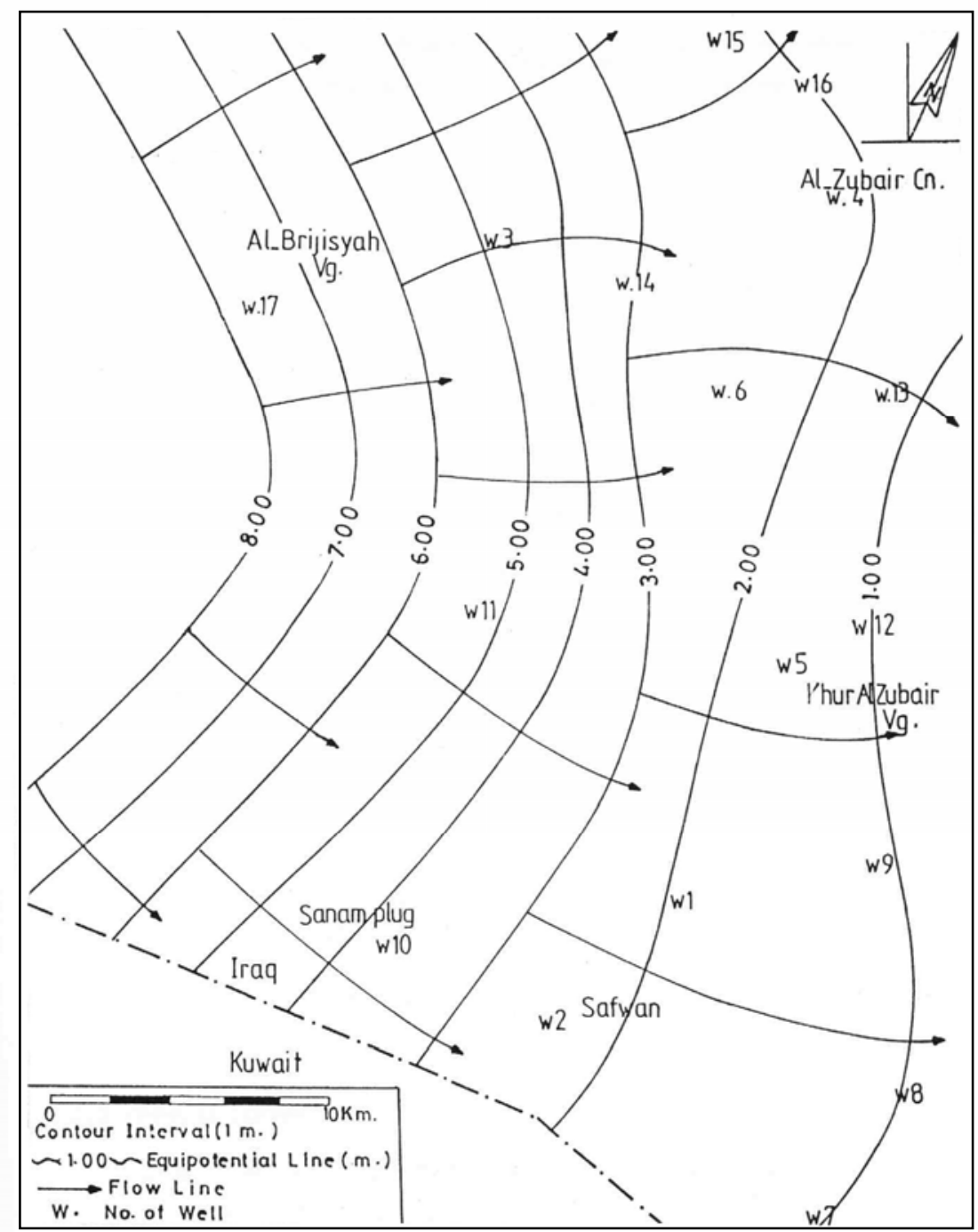

Fig. 5: Direction of flow in study area (After Al-Abadi, 2001).

\section{MODEL CALIBRATION}

The model is calibrated using trial and error procedure in two sequential stages: steady state calibration followed by transient calibration:

Calibration of steady state condition: Sixteen observation wells distributed over the study area are used to derive the initial water table, which is taken as initial water levels for the simulation (Al-Abadi, 2001), (Fig. 5). Figure (6) shows the scattergram of measured versus modeled heads. It will be obvious that these values are generally approximate to the field values such that they reflect the same general course of flow.

Unsteady state calibration: The head measurements of ten wells for ten months are used to calibrate the model in transient condition. The period of simulation is divided into three pumping periods. A (1) day time step is adopted with (1) time step multiplier. Hence, number of time steps through entire simulation period is equal to 356 . The results of steady state calibration are introduced as initial conditions for the transient calibration. In the study area there are three time periods of pumping, table (1). Relaxation period included approximately June and July, where irrigation activates was stopped. August, 
September and October represent the concentrated pumping period, while the normal pumping period has been almost in November to May rationally. The amount of pumping rate is taken in this study as $5 \mathrm{l} / \mathrm{sec}$. Since the soil in the study area does not receive water except for a very short time period, the percentage of recycled irrigation water to the unconfined aquifer storage is a bout 33\% (Nomas and Al-Asadiy, 2001). According to the comparison between the observed water level data and simulated head, (Figs. 7-9), the results indicate good agreement between observed and simulated heads. Table 2 shows unweighted groundwater levels calibration statistic (m).

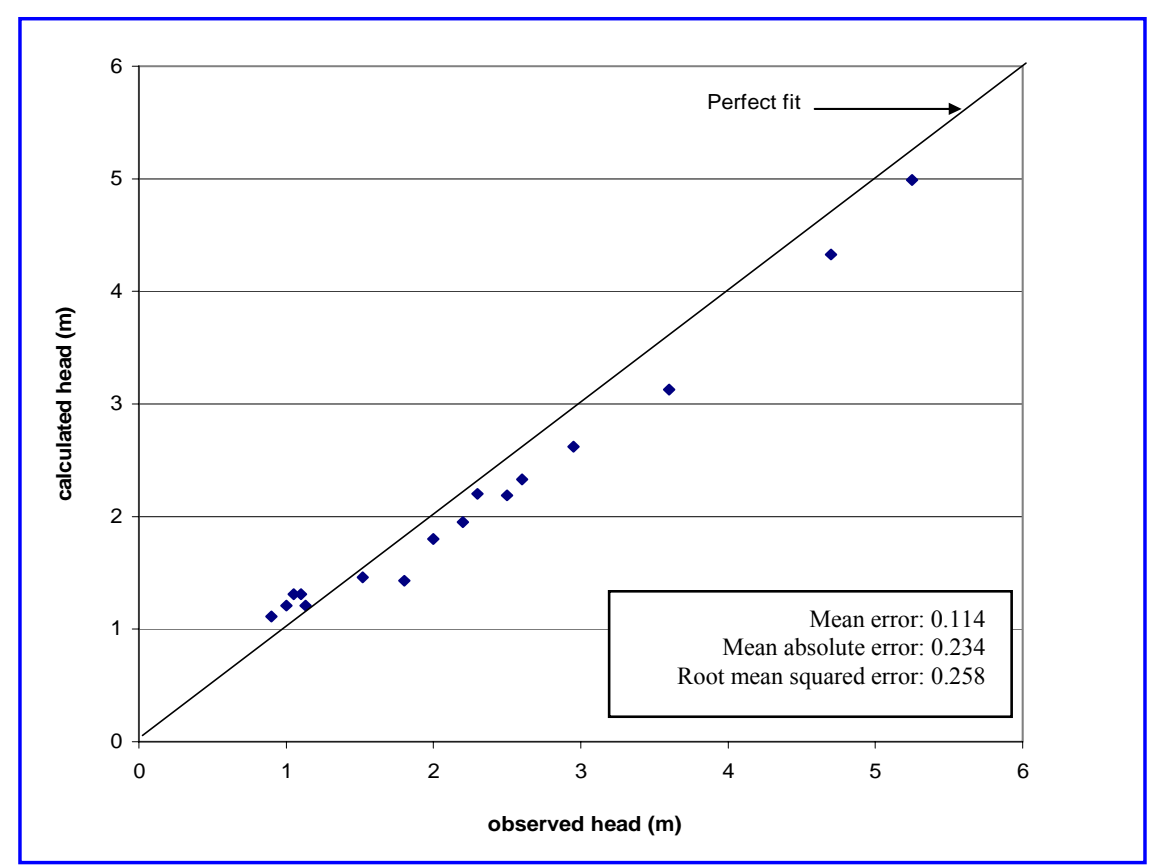

Fig. 6: The scattergram of measured versus modeled heads.

Table 1: The stress periods of pumping during twelve months.

\begin{tabular}{|l|c|c|}
\hline \multicolumn{1}{|c|}{ Stress duration } & $\begin{array}{c}\text { Pumping Hours } \\
\text { Per the day }\end{array}$ & $\begin{array}{c}\text { Percentage of } \\
\text { Pumping time }\end{array}$ \\
\hline Relaxation period (June- July) & 0.00 & 0.00 \\
\hline Concentration pumping period (August-September) & 24.00 & $100 \%$ \\
\hline Normal pumping period (December- April) & 12.00 & $50 \%$ \\
\hline
\end{tabular}

\section{SENSITIVITY ANALYSIS}

There is always some uncertainty about the accuracy of models because the model parameters are never exactly known. The importance of each input parameter and its effect on simulation results can be evaluated through sensitivity tests, in which the values of hydraulic parameters such as hydraulic conductivity value and the magnitude of change in simulated groundwater levels and flows are quantified. Results of the sensitivity analysis indicate that model is most sensitive to variations in the values of specified hydraulic conductivity in steady state flow and slightly sensitive to change the specific yield in transient flow condition. 
The Effect of a Hypothetical Artificial Recharge Program...
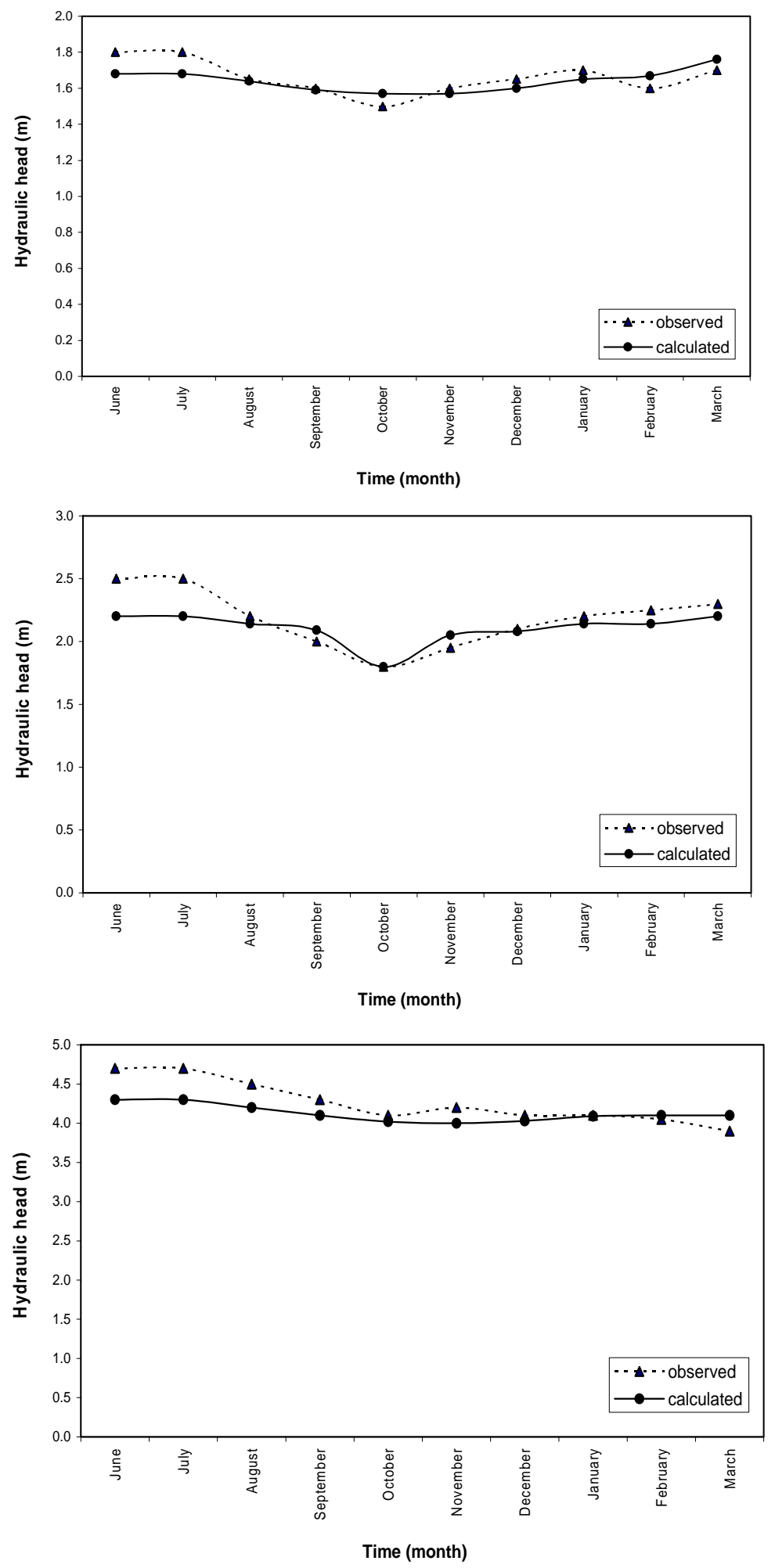

Fig. 7: Comparison between simulated and measured water table for W1, W2, and W3 observation points (calibration stage). 
Alaa M. Atia and Monera N. Sadoon
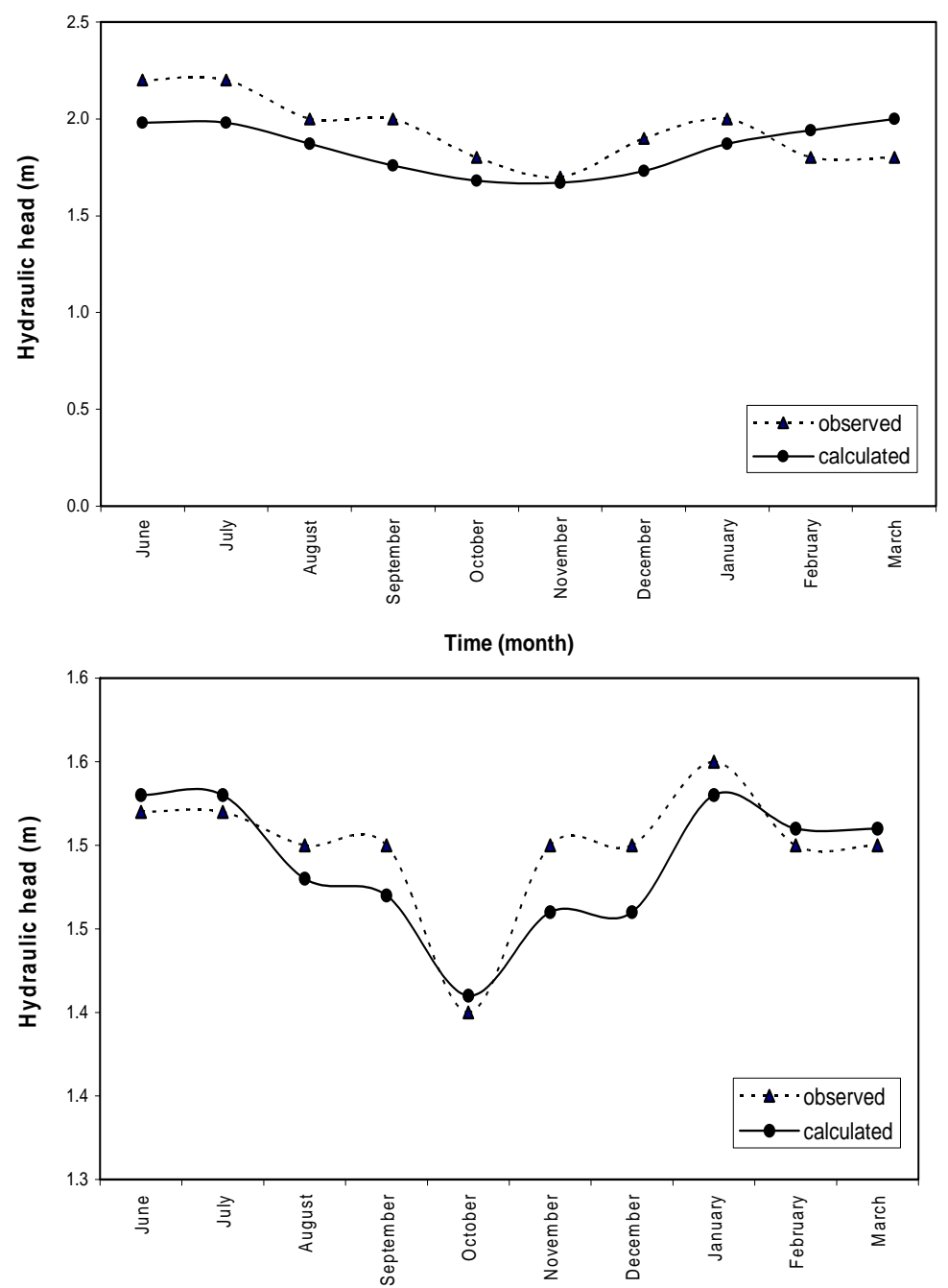

Time (month)

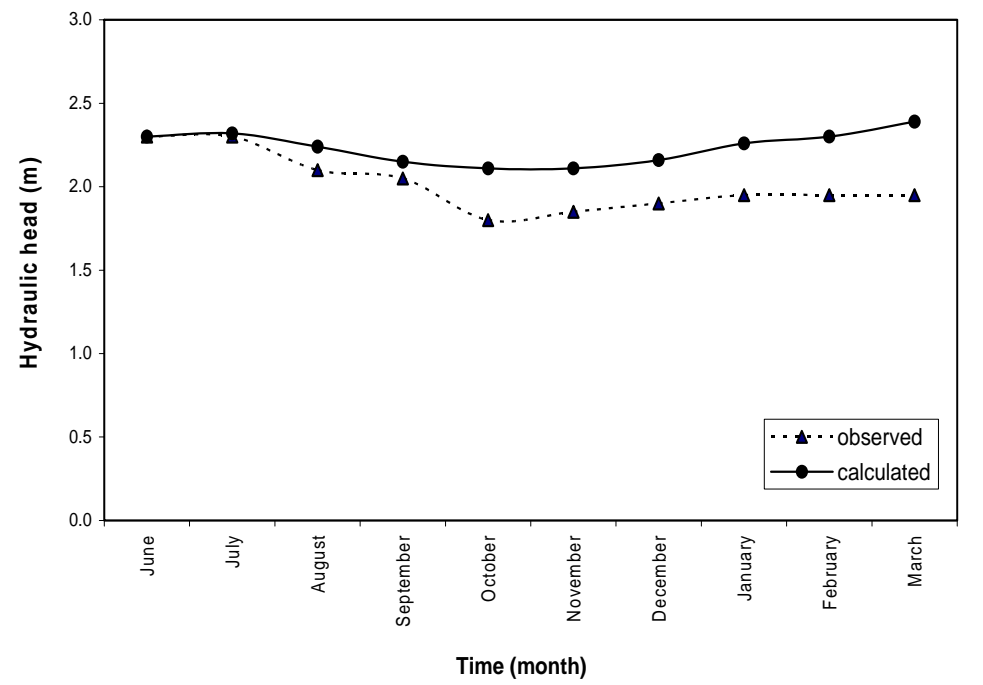

Fig. 8: Comparison between simulated and measured water table for W4, W5, and W6 observation points (calibration stage). 
The Effect of a Hypothetical Artificial Recharge Program...
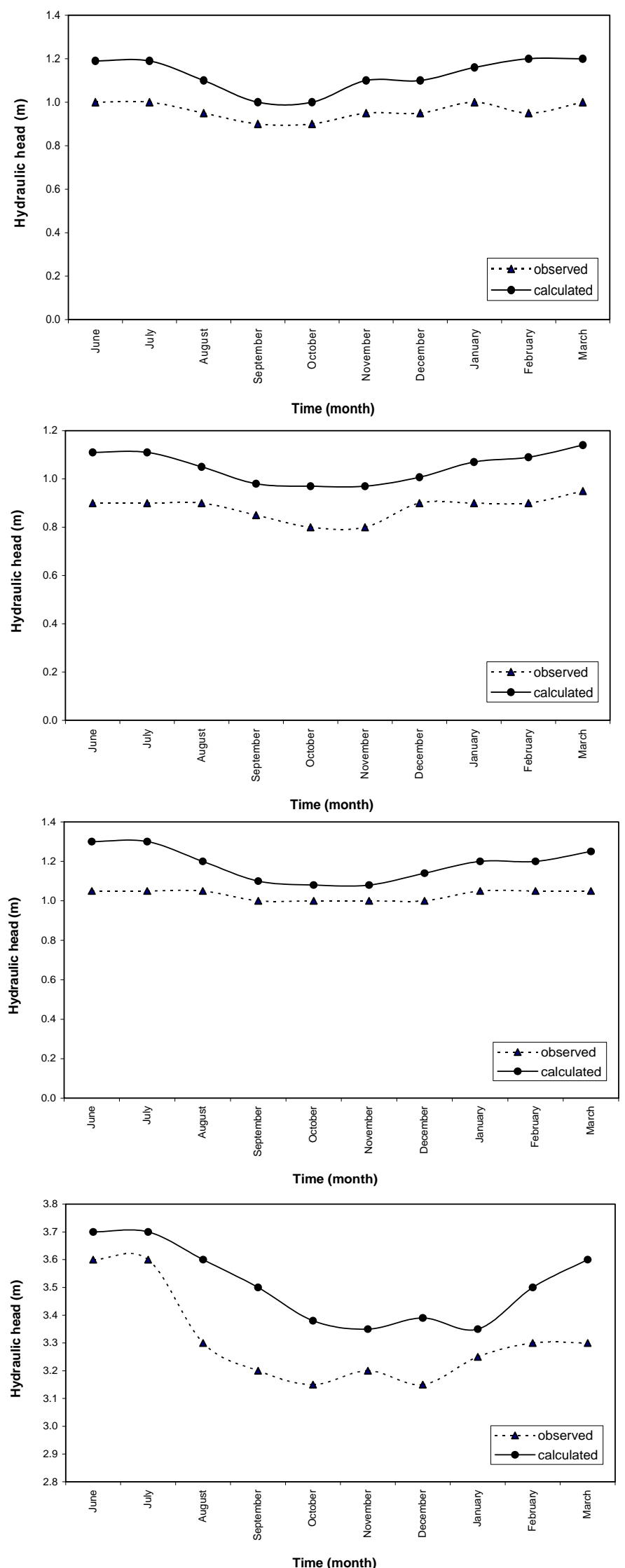

Fig. 9: Comparison between simulated and measured water table for W7, W8, W9 and W10 observation points (calibration stage). 
Table 2: Unweighted groundwater levels calibration statistic.

\begin{tabular}{|c|c|c|}
\hline \multirow{2}{*}{ Well No. } & \multicolumn{2}{|c|}{ Calibration statistics } \\
\cline { 2 - 3 } & Mean absolute error & Root mean squared error \\
\hline 1 & 0.059 & 0.069 \\
\hline 2 & 0.114 & 0.150 \\
\hline 3 & 0.191 & 0.233 \\
\hline 4 & 0.160 & 0.170 \\
\hline 5 & 0.020 & 0.023 \\
\hline 6 & 0.219 & 0.259 \\
\hline 7 & 0.164 & 0.169 \\
\hline 8 & 0.169 & 0.170 \\
\hline 9 & 0.155 & 0.165 \\
\hline 10 & 0.202 & 0.217 \\
\hline
\end{tabular}

\section{THE NEED FOR ARTIFICIAL RECHARGE IN STUDY AREA}

According to the results of previous studies (Haddad and Hawa, 1979, Al-Kubasi, 1999, and Alaa and Al-Asadi, 2005) the usable unconfined upper part of the Dibdibba aquifer in Safwan-Zubair follows the direction of mining of resource. Overdraft of groundwater in the next years will led to deplete the aquifer supply and introduce undesirable effect on it. The adequate management of the area requires (Alaa and Al-Asadi, 2005):

1. Controlling of pumping rates and duration of the existing operated wells and redistributing them uniformly over the area in order to alleviate interfering.

2. Constructing large ponds acting as surface shallow wells in order to alleviate the current overpumping of the aquifer and decrease the difference in head as possible as between the bodies of water in the area under question. The design of such ponds requires a detailed study of the dynamics of flow toward them for accurate prediction of the allowable pumping rate within the constraints of available drawdown and a given pumping time (Atiaa, 2005).

3. Control of agricultural area and type of crops. Lowers of agricultural area decreases water consumptions and losses. Select crops (like cereals with lower water consumptions) contribute in decreasing water requirements and volume of pumping (Al-Asadi et al., 2005).

4. The best alternative plan, but a difficult and an expensive one to enhance the water availability for pumping and rebalance the aquifer is by using an artificial recharge scheme. Transport of available water with good quality using an appropriate method from Shatt Al-Arab river, which is located at (30) $\mathrm{km}$ to the north east of Barjizia area during water surplus of the river is a preferable suggestion for replenishing depleted supplies and preventing a continuous deterioration of its quality. The comparison of the sum of present water requirements of Shatt Al-Arab river province (about $\left.570 \times 10^{6} \mathrm{~m}^{3} / \mathrm{y}\right)$ with available water $\left(2.2 \times 1010 \mathrm{~m}^{3} / \mathrm{y}\right)$ on the average basis demonstrates that large quantities of water are losing to the Arabian Gulf. Transfer of about $\left(96 \times 10^{6} \mathrm{~m}^{3} /\right.$ year $)$ from unused available water of Shatt Al-Arab river and recharging the aquifer artificially using an appropriate scheme (furrows and ditches are preferable method due to high infiltration capacity of exposed formation) during cold month of the year will rise its water table to the $(0.5-1 \mathrm{~m})$ and improve its groundwater quality. 


\section{PREDICTION RUNS}

Two management alternatives are undertaken by running the model with the adapted (calibrated) parameters to investigate the effect of future withdrawals and hypothetical recharge program on groundwater levels in the area of question. A planning horizon of 10 years is selected for these management plans from 2001-2010. The values of water table altitude in year 2001 are used as an initial values and the aquifer is assumed to be at psedu-state condition at that time. The main goal of these runs is to investigate benefits of artificial recharge on groundwater availability for consuming. Also, the objective includes rise of water table to $(0.5-1) \mathrm{m}$ to compensate the drained water throughout the two last decades and with continuous operating well growth. With trial and error procedure, recharging of $\left(129 \times 10^{6}\right) \mathrm{m}^{3} /$ year water quantity is sufficient to attain these objectives.

Management scenario I: Existing trends continue: The first development plan is based on that the existing trend of growth of operating wells is continuous, i.e., 200 well per year. Figure (10-12) shows the comparison between the temporal changes of groundwater levels with and without application of artificial recharge program. A continuous decline of groundwater will occur if the model is run without recharging the aquifer. The maximum and minimum drops in level are $(2.96$ and $1.142 \mathrm{~m})$ in well 3 and well 1 , respectively. Average decline of head is of about $(2.0 \mathrm{~m})$. In the case of application artificial recharge, in most of the observation wells, the simulated head are continued to rise and then decline gradually to a level that greater than that in 2000, except in well 3 and well 10 . The maximum and minimum rises in level are (1.156 and 0$)$ in well 5 and well 3, respectively. Level in well 10 is rise and then slightly declines to a value that less than that in 2000 . The average rise in head is $(0.56 \mathrm{~m})$. The trend of head decline indicates that the aquifer will be in mining conditions and the aquifer can be termed as depleted one. Depletion of storage will induced undesirable effects on the aquifer including salinization and salt water intrusion in the eastern parts of the area.

Figure (13) shows the spatial distribution of groundwater levels in 2010 in the case of applied of artificial recharge or not, respectively. As expected, owing to the increased levels of pumping water levels declines (compared to 2000) occurred throughout the whole area, with most of the predicted changes occurring in the east side ( reach to $3 \mathrm{~m}$ ) and close to the discharging areas; i.e., Khur Al-Zubair. The water table change is somewhat less on the eastern parts where the drop in head is of about $(2.0 \mathrm{~m})$.

Results of this run further indicate that water levels will not be stabilized by the year 2000 , and that they will continue to decline uniformly beyond that time. Such drop in head, if occurs, is not acceptable in the area of question because most of the hand dug wells will become completely dry.

Management scenario II: Increase of well discharge to $7 \mathbf{l} / \mathbf{s}$ : The second development plan is based on that the discharge of wells is increased to $7 \ell / \mathrm{s}$. The results of this run are similar to that in run management where the maximum and minimum drop in levels is 
(2.7 and 1.02) $\mathrm{m}$ in well 3 and well 1 , respectively. The maximum and minimum rise in levels is (1.6 and 0.11) $\mathrm{m}$ in well 5 and well 3 , respectively. The average decline of head is $(0.85) \mathrm{m}$, while the average rise of level is $(0.88) \mathrm{m}$. Figure (14) shows the spatial distribution of simulated altitudes of water table based on this simulation with and without artificial recharge, respectively.

\section{CONCLUSION AND RECOMMENDATION REMARKS}

The usable unconfined upper part of the Dibdibba aquifer in Safwan-Zubair follows the direction of mining of resource. Overdraft of groundwater in the next years will led to deplete the aquifer supply and introduce undesirable effect on it. Based on the simulation results of management plan I, the given discharge rates will lead to a groundwater level decline of about $(2 \mathrm{~m})$ at the end of given period. Such a fall in level, if occurs, is not acceptable in the area of question due to the fact that all of the hand dug wells become dry. Within Safwan-Zubair area, there are no observation wells (non-pumping wells) that are continuously monitored that are open to the upper and lower parts of usable aquifer. However, monitoring of water levels, in the both parts of aquifer, would provide a data to construct three dimensional model instead of two-dimensional one.

\section{AKNOWLEDGMENT}

We thank Mr. Mazin Al-Abadi, assistance lecturer in Department of Geology, College of Science, and University of Basrah to support this work and introduce the needed data. 
The Effect of a Hypothetical Artificial Recharge Program...
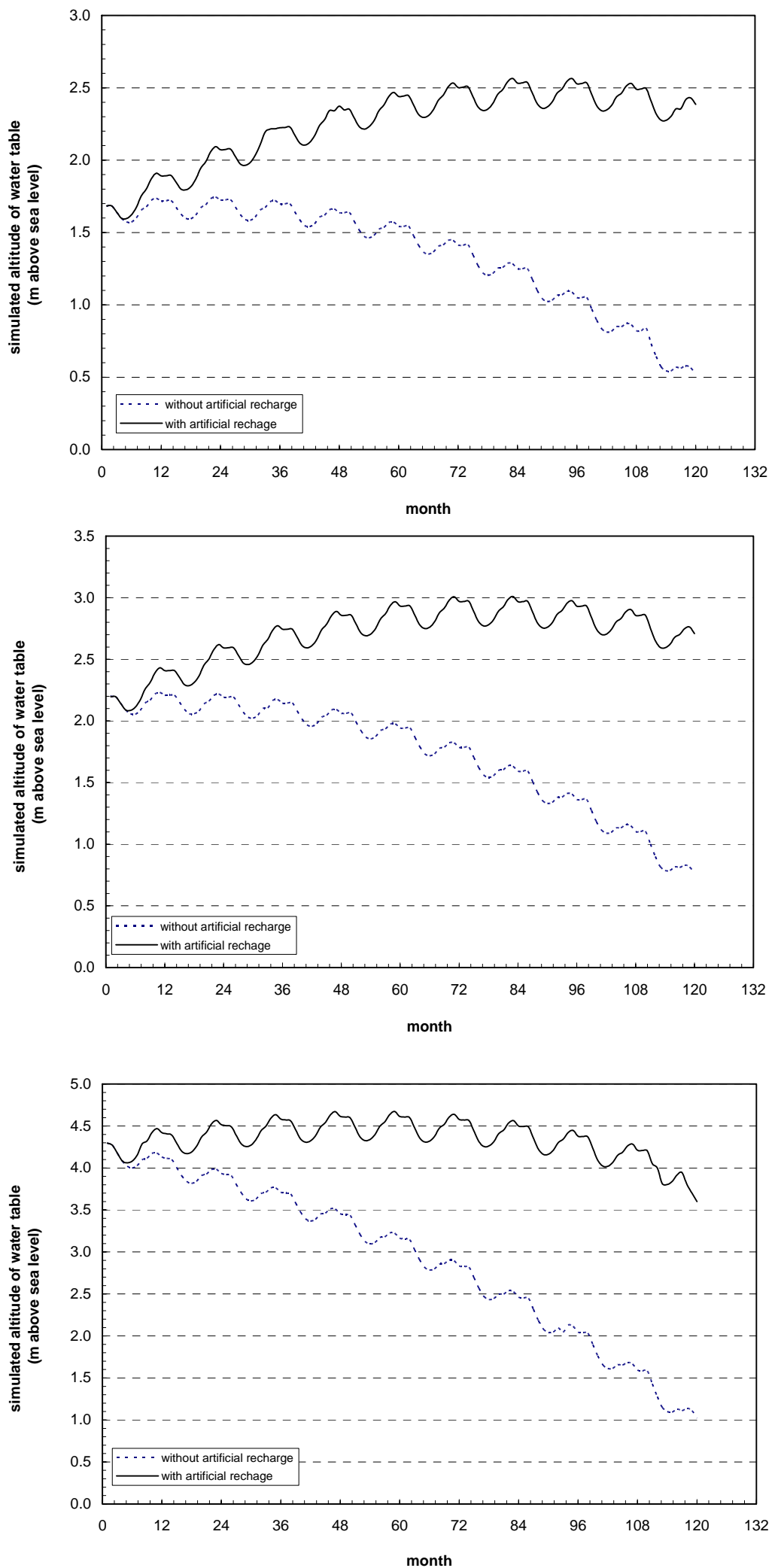

Fig. 10: Comparison between simulated altitudes of water table with and without application of hypothetical recharge program for $\mathrm{W} 1, \mathrm{~W} 2$, and $\mathrm{W} 3$ based on scenario I.. 
Alaa M. Atia and Monera N. Sadoon
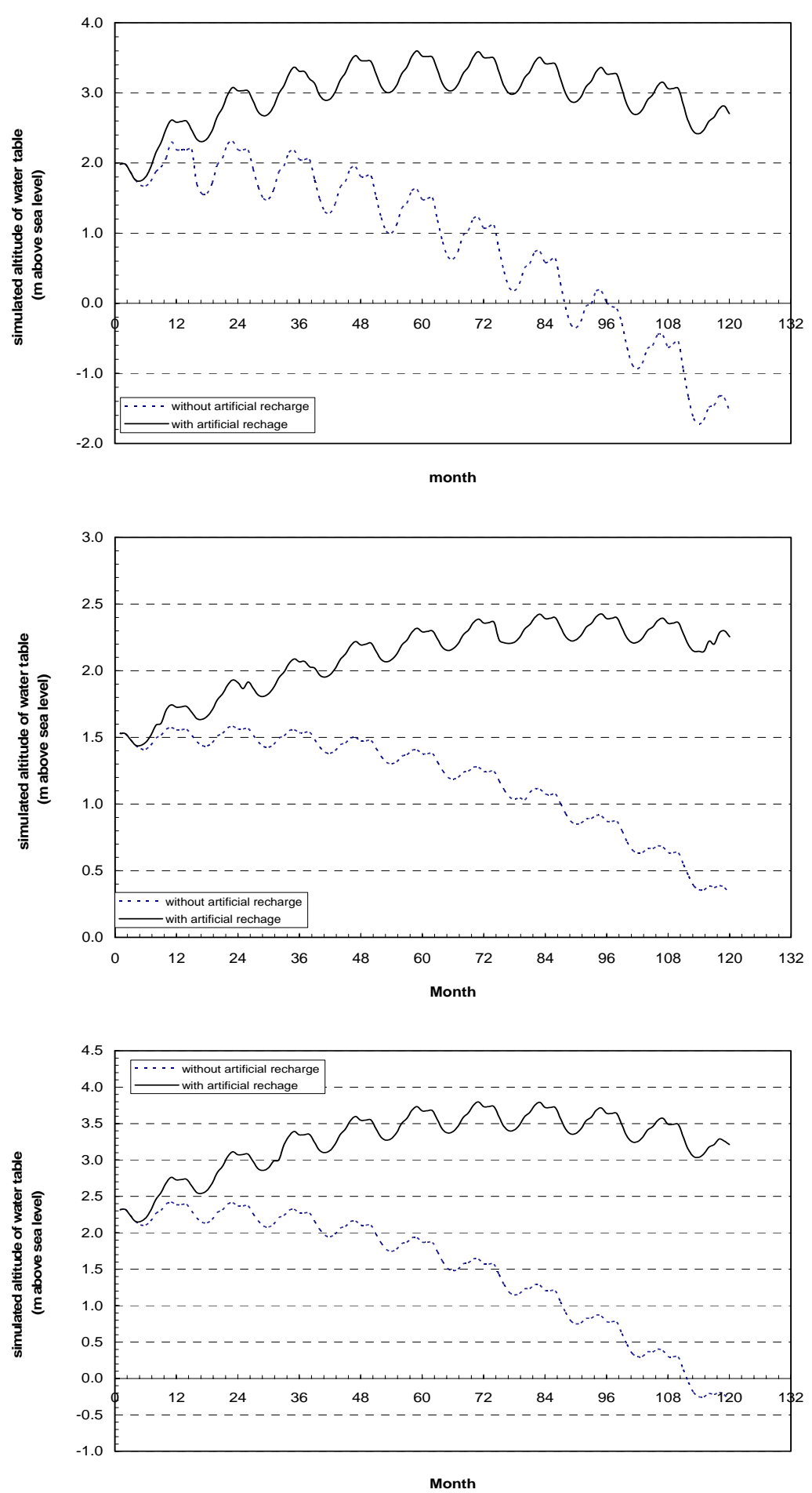

Fig.11: Comparison between simulated altitudes of water table with and without application of hypothetical recharge program for W4, W5, and W6 based on scenario I. 
The Effect of a Hypothetical Artificial Recharge Program...
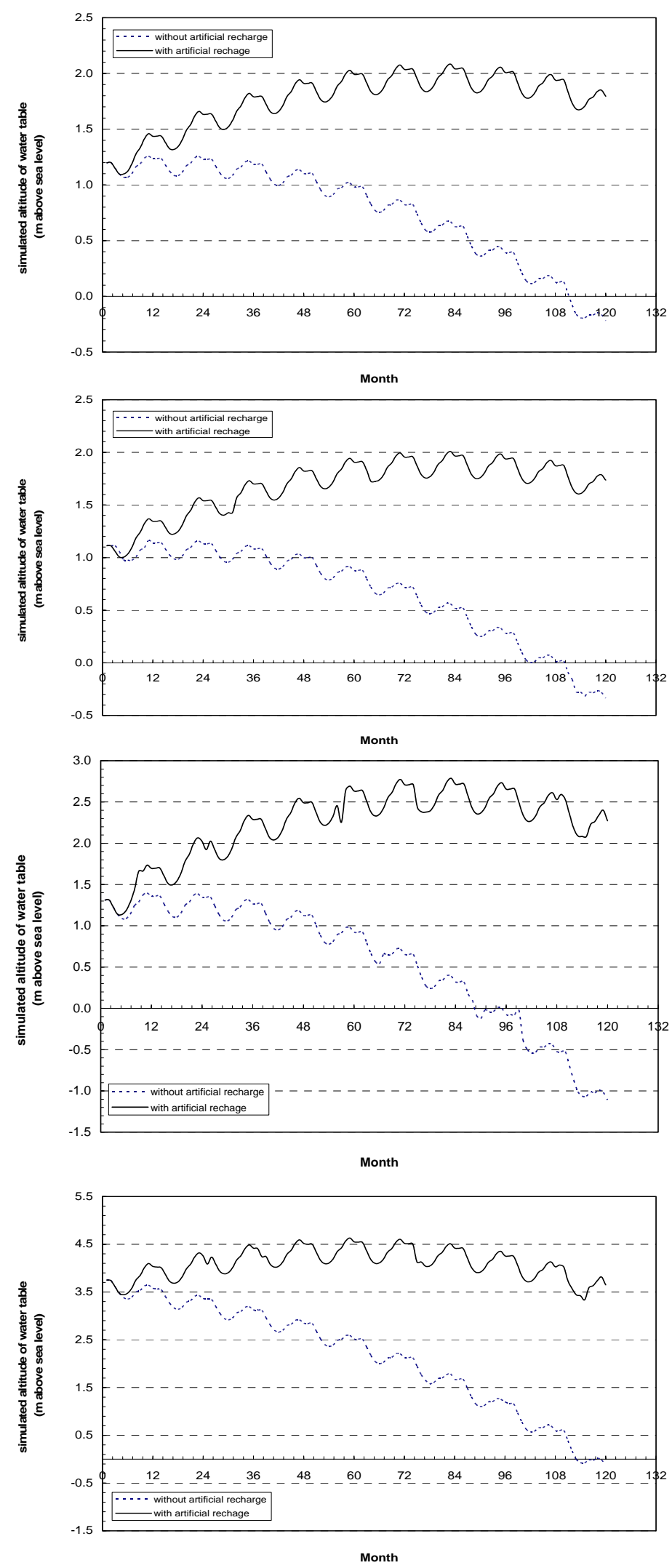

Fig. 12: Comparison between simulated altitudes of water table with and without application of hypothetical recharge program for $\mathrm{W} 7, \mathrm{~W} 8, \mathrm{~W} 9$ and $\mathrm{W} 10$ based on scenario I. 


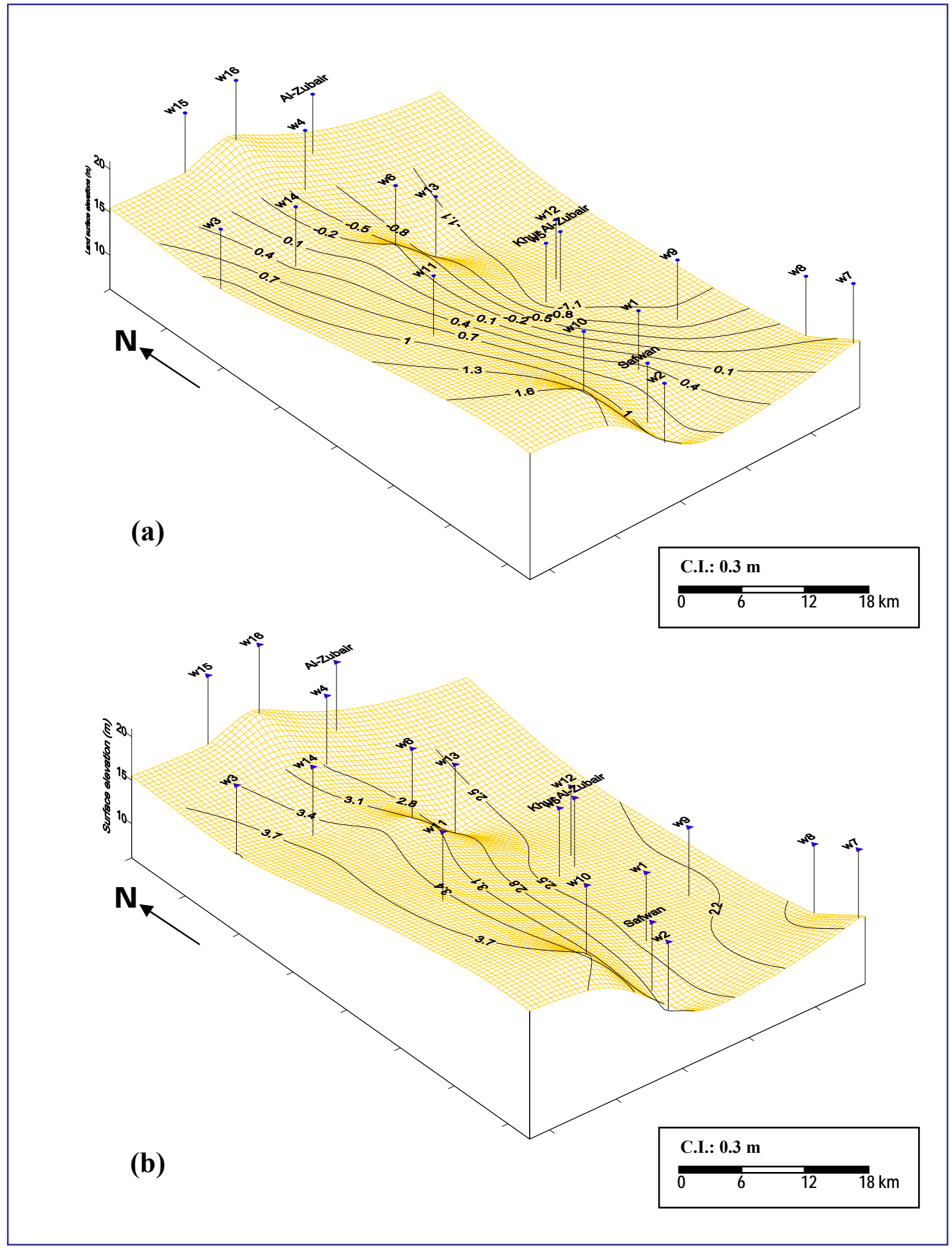

Fig. 13: The spatial distribution of groundwater levels in 2010 based on scenario I (a) without artificial recharge (b) with artificial recharge. 


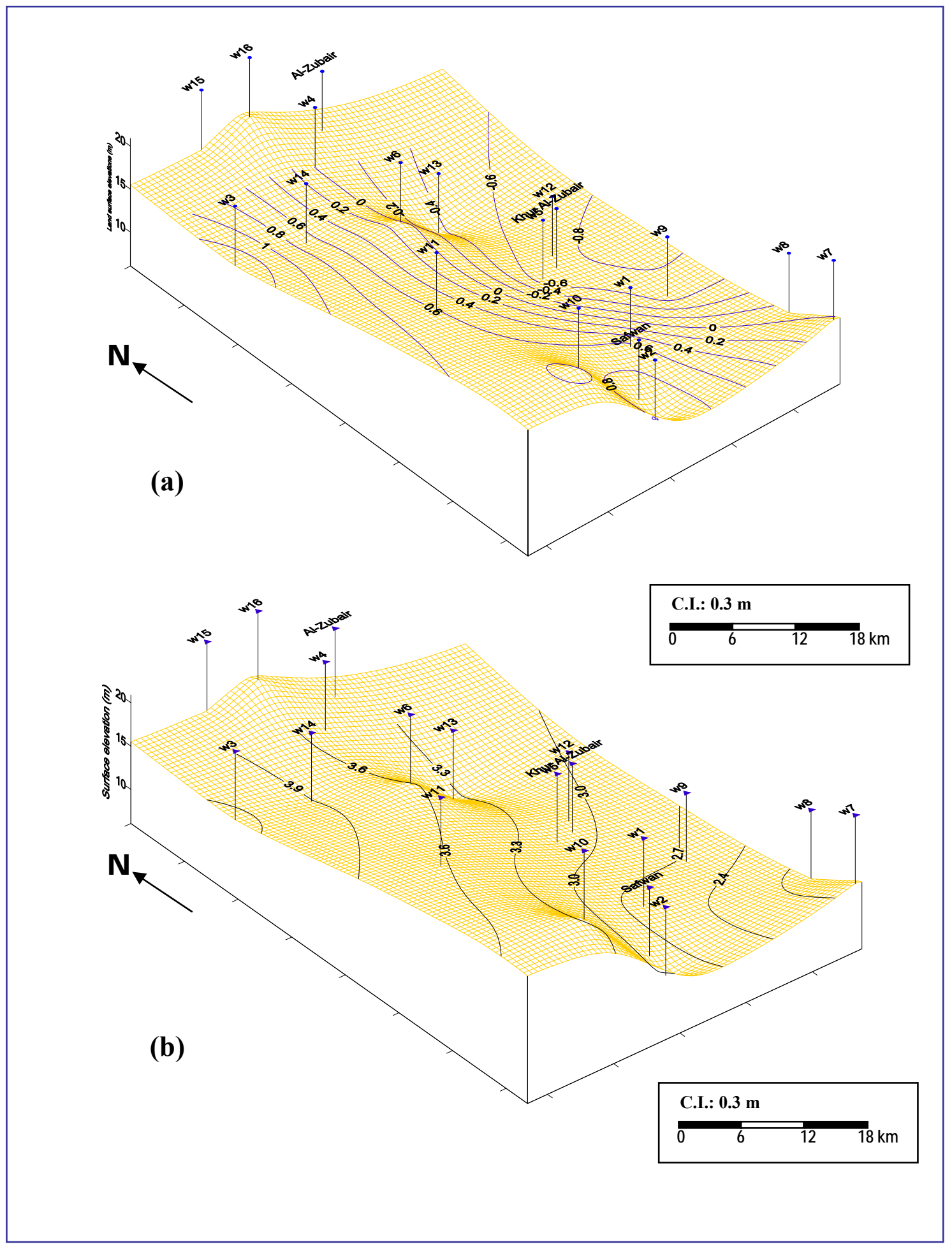

Fig. 14: The spatial distribution of groundwater levels in 2010 based on scenario II (a) without artificial recharge (b) with artificial recharge. 


\section{REFERENCES}

Al-Abadi, M.A., 2001. Optimum Management of Model of Groundwater Resources in Safwan-Zubair Area, South of Iraq. Unpub. M. Sc. Thesis, College of Science, University of Basrah, $110 \mathrm{p}$.

Alaa, M.A. and Al-Asadiy S., Abd-Al-Ameer, 2006. Management of Groundwater Resource of Dibdibba Sandy Aquifer in Safwan- Zubair Area, South of Iraq, Basrah Res. Jour., No. 81, pp.30-43.

Al-Asadi, S.A., Abdel I.A. and Al-Lami, 2005. Economical Evaluation for the Use of Irrigation Water and Agricultural Production in Basrah Governorate. Iraqi J. for Soil Science, Vol. 5, No. 1, pp.55-65.

Al-Jawad, S.A., Ayob, M.S., Khalil, S. and Al-Radi, N.H., 1989. Hydraulic Properties of Dibdibba Sandstone Using Pumping Tests Data in Large Diameter Wells. Proc. 5th, Sci., Conf., SRC., Iraq, Vol.1, Part 3, pp.133-146.

Al-Kubaisi, Q.Y., 1999. Quaternary-Tertiary Hydrogeologic Boundary Condition at Safwan-Zubair Area, South of Iraq. Iraqi Jour. Sci., Vol.40, No.3, pp.21-28.

Al-Rawi, Y., Al-Sam, S. and Skavarka, L., 1983. Hydrogeology, Hydrochemistry and Water-Resource of Southern Desert, Final Report, Vol. 9, DGGSMF, Iraq, 204 p.

Al-Suhail, Q.A., 1999. Geochemical Evaluation of Groundwater System of Dibdibba Aquifer, Southern Iraq, Basrah Jour. Scie., Vol. 17, No. 1, pp.63-72.

Al-Suhail, Q.A., Al-Mansori, H.B. and Atiaa, M.A., 2005. Determination of Hydraulic Characteristics of Dibdibba Sandy Aquifer, South of Iraq, from Pumping Tests on Large Diameter Wells Using Numerical Method, Case Study. Iraqi Basrah Jouranl, Univ. of Basrah, Vol. 23, No.1, pp.20-22.

Atiaa, M.A., 2005. A Multi-Dimensional Analysis of Hypothetical Shallow Ponds in Safwan-Zubair Area, South of Iraq. Iraqi Journal of Science, Univ. of Baghdad, (to be Published). (in Arabic)

Buday, T., 1980. The Regional Geology of Iraq, Stratigraphy and Paleogeography. Vol. 1, Dar-Al-Kutib Pub. House, Univ. of Mosul, 445 p.

Buday, T. and Jassim, S.Z., 1987. The Regional Geology of Iraq Tectonism, Magmatism, and Metamorphism. Vol. 2, Dar-Al-Kutib Pub. House, Univ. of Mosul, 352 p.

Chaing, W.H. and Kinzelbach, W., 1998. Processing Modflow, a Simulation System for Modeling Groundwater Flow and Pollution. 328 p.

Haddad, R.H. and Hawa, A.J., 1979. Hydrogeology of the Safwan-Zubair Area, South of Iraq, Tech. Bull., No. 122, Sci. Res., Foundations, Iraq, 232 p.

Nomass, H.B. and Al-Asadiy, S.A., 2001. Optimum Management of Groundwater Resource in Basrah Province, Basrah Res. Jour., Vol. 21, No. 3, pp. 100-130 (in Arabic) 